\title{
How to Get Information in Online Environments? A Comparison of the Use of Net Generation Tools
}

\begin{tabular}{ccc}
\hline $\begin{array}{c}\text { Article Type } \\
\text { Research }\end{array}$ & $\begin{array}{c}\text { Received Date } \\
19.06 .2020\end{array}$ & $\begin{array}{c}\text { Accepted Date } \\
\text { Nazire Burçin Hamutoğlu* }\end{array}$ \\
Orhan Gemikonakli*** $^{* * * 2021}$
\end{tabular}

\begin{abstract}
It is anticipated that there will be differences in the use of the Internet and mobile technologies in accessing information amongst the new generations (digital natives) depending on the development level of the country they live in. Globalization further reinforces these differences. In this study, these differences are investigated for three countries having different levels of development: the United Kingdom, Malta, and Turkey. A total of 443 participants are chosen from university universities studying in different departments in 2017-2018 spring term. Variance analysis (ANOVA) has been used in identifying the differences between the study groups' access to information of the three countries. Findings show differences between the three countries in the use of social networks such as Facebook, Instagram, Twitter and Snapchat. In addition, there are differences in the use of mobile technology devices Notebook, Tablet and Smartphones in accessing information. Finally, differences were identified in the use of information sources in accessing information. These differences are in the use of search engines, wiki, social networks, blogs, and digital libraries. No differences were found in terms of digital newspapers. The findings are discussed comparatively with reference to the scholarly work done in the field and recommendations are given.
\end{abstract}

Keywords: Accessing information, ANOVA, net generation tools, comparative study.

\footnotetext{
* Corresponding Author: Dr., Eskisehir Technical University, The Centre for Teaching and Learning, Eskisehir, Turkey. E-mail: nbhamutoglu@ eskisehir.edu.tr, 0000-0003-0941-9070

***Assoc. Prof. Dr., Trakya University, Computer and Instructional Technology Education, Edirne, Turkey. E-mail: mertkan@trakya.edu.tr, 0000-0003-4688-043X

${ }^{* * *}$ Prof. Dr., Final International University, Faculty of Engineering, Catalkoy/Girne, Turkish Republic of Northern CyprusTRNC, E-mail: orhan.gemikonakli@ final.edu.tr, 0000-0002-0513-1128

***** Lecturer, Middlesex University, School of Science and Technology, Malta. E-mail: s.camilleri@ mdx.ac.uk, 0000-0001-55181353
} 


\title{
Çevrimiçi Ortamlarda Bilgiye Nasıl Ulaşılır? Y Kuşağı Teknolojik İletişim Araçları Kullanımının Karşılaştırılması
}

\begin{tabular}{|c|c|}
\hline $\begin{array}{l}\text { Makale Türü } \\
\text { Araştırma }\end{array}$ & $\begin{array}{c}\text { Kabul Tarihi } \\
9.06 .2021 \\
\end{array}$ \\
\hline Nazire Burçin Hamutoğlu* & Deniz Mertkan Gezgin** \\
\hline Orhan Gemikonakli ${ }^{* * *}$ & Steven Camilleri $^{* * * *}$ \\
\hline
\end{tabular}

\begin{abstract}
$\ddot{O} \mathbf{z}$
Yeni nesil olarak ifade edilen dijital yerlilerin küreselleşme ile birlikte bilgiye ulaşmada internet ve mobil teknolojileri kullanım davranışlarının ülkelerin gelişmişlik düzeylerine göre farklılaşacağ 1 düşünülmektedir. Bu çalışmada farklı gelişmişlik düzeyine sahip İngiltere, Malta ve Türkiye olmak üzere üniversite öğrencilerinin bilgiye ulaşmada kullandıkları yeni nesil çevrimiçi araçlar ve mobil teknolojilerin kullanımının karşılaştırmalı olarak araştırılması amaçlanmaktadır. Çalışma grubu 2017-2018 bahar döneminde üniversitelerin farklı bölümlerinde öğrenim görmekte olan toplam 443 öğrenciden oluşmaktadır. Çalışmada değerlendirilen ülkeler arasındaki farklılıkların belirlenmesinde ANOVA kullanılmıştır. Elde edilen sonuçlar, ülkelerin bilgiye erişimde kullandıkları sosyal ağların Facebook, Instagram, Twitter ve Snapchat açısından farklılaştığını ortaya koymaktadır. Bununla birlikte mobil teknolojik cihazlar açısından bakıldığında bilgiye erişmede Notebook, Tablet ve Akıllı Telefon kullanımının da ülkeler açısından farklılaştı̆̆ını ilişkin bulguya rastlanmıştır. Son olarak, ülkelerin bilgiye ulaşmada çevrimiçi bilgi kaynaklarının kullanımına ilişkin olarak farklılaştığını göstermektedir. Buna gore, arama motoru, wiki, sosyal ağlar, blog, dijital kütüphane açısından farklılık tespit edilirken; dijital gazete açısından ülkeler arasında herhangi bir farklılık görülmemektedir. Çalışmada elde edilen sonuçlar alanyazın temelinde kültürel karşılaştırmalı olarak tartışılmış ve öneriler sunulmuştur.
\end{abstract}

Anahtar Sözcükler: Bilgiye erişim, ANOVA, yeni nesil dijital araçlar, karşılaştırma.

\footnotetext{
* Sorumlu Yazar: Dr., Eskisehir Teknik Üniversitesi, Öğrenme ve Öğretme Gelişimi Birimi, Eskişehir, Türkiye. E-posta: nbhamutoglu@eskisehir.edu.tr, 0000-0003-0941-9070

** Doç. Dr., Trakya Üniversitesi, Bilgisayar ve Öğretim Teknolojileri Eğitimi Bölümü, Edirne, Türkiye. E-posta: mertkan@ trakya.edu.tr, 0000-0003-4688-043X

${ }^{* * * *}$ Prof. Dr., Uluslararası Final Universitesi, Mühendislik Fakültesi, Catalkoy/Girne, Kuzey Kıbrıs Türk Cumhuriyeti-KKTC. E-posta: orhan.gemikonakli@ final.edu.tr, 0000-0002-0513-1128

***** Okutman, Middlesex Üniversitesi, Bilim ve Teknoloji Fakültesi, Malta. E-posta: s.camilleri@mdx.ac.uk, 0000-0001-55181353
} 


\section{Introduction and Literature Review}

The introduction of new technology enabled approaches to education has reached a point that educationalists have no choice but finding ways of the best use of these approaches. The Net Generation come with their own tools and approaches to learning, so that even the most conservative teaching and learning environments are forced to accept these tools and approaches. Recent statistics published by the International Telecommunications Union (ITU 2019) show that while there is a decline in the subscription to fixed telephone devices, subscription to mobile devices is estimated to exceed $100 \%$ worldwide (including individuals with multiple cell phones). The same source states that while more than $100 \%$ of the population has active mobile broadband subscriptions, the same is around $75 \%$ in the developing world. When tablets and other portable, wireless devices are considered alongside mobile phones, mobile systems have become the main technology in accessing online systems. Considering that access to broadband services is also widely provided by institutions, it becomes clear that important percentages of people access online systems worldwide (48\% of females and 58\% of males worldwide (53.6\% combined)). When broken down according to development levels, access to the Internet is $86.6 \%$ and $47 \%$ for the developed and the developing world respectively. Hence, the important role of these devices in accessing information, and promoting education become undeniable. As such developments facilitate effective communication, online information resources and social networks provide platforms for not only socializing and entertainment but also sharing information, and collaboration.

Sanders and Morrison (2007) describe the net generation as "the cohort of young people born between 1982 and 1991 who have grown up in an environment in which they are constantly exposed to computer-based technology." The definition of digital natives to identify the $21^{\text {st }}$ century children and youth reflects the level of the use of the new mobile technologies such as smartphones, Notebooks, PDAs, and tablets (Prensky, 2001). The mobile applications developed for these devices are widely used for entertainment, socialization, and access to information (Tonta, 2019) as well as for teaching and learning (Gülbahar, Kalelioğlu, and Madran, 2010) by students. Their experience in the use of online systems such as social networks, blogs, wikis etc., result in a different approach to learning compared to previous generations. Investigating the net generation's reading preferences with reference to print and e-books, Saleh and Mashhur (2015) conclude that although e-book growth is slowing, it is still substantial. According to the study, the majority of book readers believe that e-books will become more popular than the printed books in the future.

The digital natives prefer to access knowledge through search engines and social media rather than printed material (Bilgiç, Duman, and Seferoğlu, 2011). The digital natives reach the desired knowledge speedily using their skills and technology (Taş, Demirdöğmez, and Küçükoğlu, 2017, s.103). They are born into a world of technology and hence demonstrate a different approach to life, socialization, the perception of knowledge, and decision making compared to the previous generations (Artemova, 2018, p.8). Although this approach is attributed to technological developments, (Leitch and Warren, 2011), it is essential to understand their aims of using the existing technologies. Gezgin, Hamutoğlu, Samur and Yildirim (2018) showed that mobile devices are predominantly used for accessing the social media. Similarly, Norman et al. (2015) highlights that mobile social media learning is an amalgamation of "mobile learning" and "social media", thereby creating a scenario where mobile technology is used within the learning process. When reviewing learning, it is imperative to consider the parties that are engaged within the domain; instructors and students. The studies referenced above show the importance of understanding which devices are used by the new generation students in accessing knowledge and learning. This way, the characteristics of the mostly used Web 2.0 technologies can be identified and integrated into learning environments to enhance teaching and learning.

Web 2.0 has enabled better functionality of the Internet-based web technologies and facilitated sharing information freely and easily over the Internet (Karaman, Yıldırım, and Kaban, 2008). Blogs, microblogs (e.g. Twitter and Tumblr), Wikis, bookmarking (e.g. Delicious), media sharing sites (e.g. Youtube and Flickr), podcasts, virtual worlds (e.g. Secondlife), and social networks (e.g. Facebook,Instragram, Myspace, and Friendfeed) are the most popular examples of Web 2.0 applications (Sahin, Kaynakçi, and Aytop, 2016). In addition, the increasing use of social networks which are popular amongst digital natives (e.g. Facebook, Instagram, Twitter, Myspace, Linkedin, and Google Plus) gave 
rise to the widening of the accessible sources of information (Togay, Akdur, Yetişken, and Bilici, 2013). The List of Millennial Characteristics state that the fast development of social networks, tablets and smart applications during the era digital natives are born and developed helped them to develop skills in the use of technology (Lucky, 2017). Although the typical characteristics of digital natives stem from the technological devices used to access and share information brought by globalization, it is essential to investigate their use of technological devices in accessing information based on the level of development of the countries they live in.

\section{The Aim and Significance of the Study}

While it may be expected that the usage behavior of the Internet and other technologies will demonstrate similarities across the world due to globalization, there may be differences amongst countries due to the cultural diversity, the level of development impacting on the policies of the use of technology in education, technological transformations, and economical factors. Alongside technological transformation, the emerging technologies of $21^{\text {st }}$ century (e.g. machine learning and artificial intelligence) may increase the differences between human groups or countries leading concerns of uncertainty for the future (UNDP, 2019). To alleviate inequalities, it is essential to have effective access to technology to succeed in transforming the societies from basic capabilities to more advanced ones. It is concerning to see that masses lag behind in accessing technology and this further increases inequalities in acquiring technological capabilities. As the Human Development Index Report indicates, effective access to technology and access to information and life changing technologies are vital for development and living standards of societies. Turkey's ranking in the human development indexes published in 2018 is 59. The UK and Malta occupy $15^{\text {th }}$ and $28^{\text {th }}$ places respectively (UNDP, 2019). Considering the contribution of digital natives to human development, an understanding of the differences between the digital natives' access to information in developing and developed countries will give an insight into these rankings. It worth noting that just like the UK, in Malta English is the dominant language used in technological development as well as education and both countries invest into the use of technology in education significantly. PISA 2018 reports show that after a sharp fall in 2015, Turkey's performance in education improved to the highest level of the past 15 years (PISA, 2018). This can be attributed to the investment into technological infrastructure and improvements in accessing information through the use of technology. Societies have differences in the use of mobile communication devices, social networks, and online information resources. Hence, it is important to investigate how these differences portray themselves. In this context, this study investigates the use of Net Generation Tools to access information through online systems comparing three countries: The UK, Turkey, and Malta. Answers are sought for the following research questions: (1) What are the differences in the use of social network types among countries for accessing information? (2) What are the differences in the use of mobile technological devices among countries for accessing information? (3) What are the differences in the use of online information resources among countries for accessing information?

\section{Method}

This study presents quantitative research designed around an exploratory survey design model (an approach aiming at describing a situation the way it exists) in an attempt to compare cultural differences in Net Generation university students' interaction with online systems especially in their education in three different countries. The sampling method of the study is a kind of convenience sampling. In convenience sampling, when subjects are chose because of the close proximity to a researcher, that is, the ones that are easier for the researcher to access (Etikan, Musa and Alkassim, 2016, p.1). Addition to this, the survey design studies do not have effort to change or influences on the fact that is the subject of the study. Accordingly, as stated in the study of Fraenkel and Wallen (2006) in the survey design studies the distribution of participants in the sample is more important than the reasons of properties and opinions.

\section{Sample}

Participants of the study consist of 443 students studying in the spring semester of 2017-2018. These students study in a department on technology in Turkey, Malta and the United Kingdom. The universities where data collected are University of Sakarya (Turkey), and Middlesex University with 
participation from London and Malta campuses. The reason for obtaining data from those countries and departments is related with the conveinced sampling method of the study.

\section{Data Collection Tools}

Through a survey, the students were asked questions such as "Which social networks do you use to get information?", "Which of the following technology/technologies do you use to aid your learning?", and "What means do you use to access information?"

\section{Data Collection Procedure}

The data has been collected from three countries; Turkey, Malta, and the United Kingdom. Participants were chosen from amongst students studying at technology related departments of universities in these countries. The reason for obtaining data from those countries and departments is related with the conveinced sampling method of the study. A total of 443 students responded to the questionnaire studying in different departments in 2017-2018 spring term. Participation was voluntary. Both a hardcopy and an electronic version of the questionnaire were used in data collection. For the electronic version Google Forms was used and the link was shared with the students electronically.

\section{Data Analysis}

The data collected was analyzed by Statistical Package for Social Sciences (SPSS) 23. The datasets collected in different countries were successfully checked for normality $(p>.05)$ enabling the application of parametric tests. To establish the differences between the countries considered, ANOVA was used during the analyses for the independent variables of the use of social networks, the use of mobile technologies, and the use of online information resources.

\section{Ethical Permits of the Research}

In this study, all the rules stated in the "Higher Education Institutions Scientific Research and Publication Ethics Directive" were followed. None of the actions specified under the second section of the Directive, "Scientific Research and Publication Ethics Actions" have been carried out.

\section{Findings}

The findings of research conducted in order to identify the characteristics of, and the differences between university students studying at different countries, in terms of the use of social networks, mobile devices, and online resources are presented in the order of the research questions stated above.

\section{Statistics of the Use of Digital Environments}

Results of the percentages (\%) and frequencies (f) for comparing variation of the use of digital environments by participants based at different countries are presented in Table 1.

\section{Table 1}

Statistics of the Use of Digital Environments

\begin{tabular}{cccccccc}
\hline Type & Choices & \multicolumn{2}{c}{ Turkey } & \multicolumn{2}{c}{ Malta } & \multicolumn{2}{c}{ UK } \\
& & $\mathbf{N}$ & $\mathbf{\%}$ & $\mathbf{N}$ & $\mathbf{\%}$ & $\mathbf{N}$ & \% \\
\hline \multirow{2}{*}{ The use of Social } & Facebook & 181 & 90 & 115 & 98.3 & 96 & 76.8 \\
networks & Twitter & 104 & 51.7 & 21 & 17.9 & 42 & 33.6 \\
& Instagram & 162 & 80.6 & 51 & 43.6 & 73 & 58.4 \\
& Swarm & 91 & 45.3 & 0 & 0.0 & 1 & 0.8 \\
The use of Mobile & Snapchat & 107 & 53.2 & 35 & 29.9 & 60 & 48.0 \\
\cline { 2 - 7 } Technologies & Notebook & 191 & 95 & 117 & 100 & 124 & 99.2 \\
& Tablet PC & 37 & 18.4 & 39 & 33.3 & 44 & 35.2 \\
The use of Online & Smartphone & 197 & 98.0 & 87 & 74.4 & 98 & 78.4 \\
\cline { 2 - 7 } Information & Search engine & 199 & 99.0 & 116 & 99.1 & 124 & 99.2 \\
Resources & wiki & 195 & 97.0 & 106 & 90.6 & 118 & 94.4 \\
& social networks & 186 & 92.5 & 91 & 77.8 & 103 & 82.4 \\
& blog & 188 & 93.5 & 99 & 84.6 & 97 & 77.6 \\
& digital libraries & 186 & 92.5 & 114 & 97.4 & 120 & 96.0 \\
& digital newspapers & 170 & 84.6 & 99 & 84.6 & 96 & 76.8 \\
\hline
\end{tabular}


Table 1 shows that the social network, Facebook has the highest percentage of use compared to other social network tools in Turkey $\left(\mathrm{X}_{\mathrm{T}}=90.0\right)$, Malta $\left(\mathrm{X}_{\mathrm{M}}=98.3\right)$, and the $\mathrm{UK}\left(\mathrm{X}_{\mathrm{UK}}=76.8\right)$. In addition to this, while smartphone has the highest usage percentage $\left(X_{T}=98.0\right)$ compared to notebook usage $\left(X_{T}=95.0\right)$ and tablet pc $\left(X_{T}=18.4\right)$ in Turkey, notebook $\left(X_{M}=100.0 ; X_{U K}=99.2\right)$ is the most used mobile technology compared to tablet pc $\left(\mathrm{X}_{\mathrm{M}}=33.2 ; \mathrm{X}_{\mathrm{UK}}=35.2\right)$ and smartphone $\left(\mathrm{X}_{\mathrm{M}}=74.4 ; \mathrm{X}_{\mathrm{UK}}=78.4\right)$ in Malta and the UK. Finally, while search engine $\left(X_{T R}=99.0 ; X_{M}=99.1 ; X_{U K}=99.2\right)$ is the most used tool as an online information resource in all three countries; social networks $\left(\mathrm{X}_{\mathrm{M}}=77.8 ; \mathrm{X}_{\mathrm{UK}}=82.4\right)$ and blogs $\left(\mathrm{X}_{\mathrm{M}}=84.6 ; \mathrm{X}_{\mathrm{UK}}=77.6\right)$ are not preferred as online information resources in Malta and the UK compared to Turkey's usage of social networks $\left(X_{T R}=92.5\right)$ and blogs $\left(X_{T R}=93.5\right)$.

\section{The Use of Social Networks}

Results of the ANOVA test for comparing variation of the use of social networks by participants based at different countries are presented in Table 2 .

Table 2

ANOVA Test based on Usage of Social Networks

\begin{tabular}{|c|c|c|c|c|c|c|c|}
\hline & $\begin{array}{l}\text { Source of } \\
\text { variation }\end{array}$ & $\begin{array}{l}\text { Sum of } \\
\text { squares }\end{array}$ & df & $\begin{array}{l}\text { Means of } \\
\text { squares }\end{array}$ & $\mathbf{F}$ & $\mathbf{p}$ & $\begin{array}{l}\text { Significant } \\
\text { Variation }\end{array}$ \\
\hline \multirow{3}{*}{ Facebook } & Among & 2.881 & 2 & 1.440 & \multirow{3}{*}{15.002} & \multirow{3}{*}{$0.00 * *$} & \multirow{3}{*}{$1-3,2-3$} \\
\hline & $\begin{array}{l}\text { groups } \\
\text { Within }\end{array}$ & 42.248 & 440 & 0.096 & & & \\
\hline & groups & 45.129 & 442 & & & & \\
\hline \multirow{3}{*}{ Twitter } & Among & 8.737 & 2 & 4.369 & \multirow{3}{*}{20.168} & \multirow{3}{*}{$0.00 * *$} & \multirow{3}{*}{$1-2,1-3,3-2$} \\
\hline & groups & 95.308 & 440 & 0.217 & & & \\
\hline & $\begin{array}{l}\text { groups } \\
\text { Total }\end{array}$ & 104.045 & 442 & & & & \\
\hline \multirow{3}{*}{ Instagram } & $\begin{array}{l}\text { Among } \\
\text { groups }\end{array}$ & 10.789 & 2 & 5.394 & \multirow{3}{*}{26.207} & \multirow{3}{*}{$0.00 * *$} & \multirow{3}{*}{$1-2,1-3,3-2$} \\
\hline & Within & 90.570 & 440 & 0.206 & & & \\
\hline & $\begin{array}{l}\text { groups } \\
\text { Total }\end{array}$ & 101.359 & 442 & & & & \\
\hline \multirow{3}{*}{ Snapchat } & $\begin{array}{l}\text { Among } \\
\text { groups }\end{array}$ & 4.122 & 2 & 2.061 & \multirow{3}{*}{8.574} & \multirow{3}{*}{$0.00 * *$} & \multirow{3}{*}{$1-2,3-2$} \\
\hline & Within & 105.77 & 440 & 0.24 & & & \\
\hline & Total & 109.892 & 442 & & & & \\
\hline
\end{tabular}

Table 2 shows that a meaningful difference is found in the results of the ANOVA test among countries for Facebook $(\mathrm{F}=15.00, \mathrm{p}<.01)$; Twitter $(\mathrm{F}=20.17, \mathrm{p}<.01)$; Instagram $(\mathrm{F}=26.21, \mathrm{p}<$ $.01)$, and Snapchat $(\mathrm{F}=8.57, \mathrm{p}<.01)$. Post hoc significant difference (Scheffe) results were interpreted in order to find which countries had differences on the use of web 2.0 tools. Results show differences in the use of Facebook between the UK and Turkey, as well as the UK and Malta; in the use of Twitter and Instagram between Turkey and Malta, between Turkey and the UK, and between Malta and the UK. Finally, there is a difference in the use of Snapchat between Turkey and Malta, and Malta and the UK.

Positive responses from the participants regarding the use of social media, can be summarised as follows in descending order:

- Facebook: Malta $\left(\mathrm{X}_{\mathrm{M}}=0.98\right)$, Turkey $\left(\mathrm{X}_{\mathrm{T}}=0.90\right)$, UK $\left(\mathrm{X}_{\mathrm{UK}}=0.77\right)$,

- Twitter and Instagram: Turkey $\left(\mathrm{X}_{\mathrm{T}}=0.52\right.$ and $\left.\mathrm{X}_{\mathrm{T}}=0.81\right)$, $\mathrm{UK}\left(\mathrm{X}_{\mathrm{UK}}=0.34\right.$ and $\left.\mathrm{X}_{\mathrm{UK}}=0.59\right)$, Malta $\left(\mathrm{X}_{\mathrm{M}}=0.18\right.$ and $\left.\mathrm{X}_{\mathrm{M}}=0.44\right)$.

- Snapchat: Turkey $\left(\mathrm{X}_{\mathrm{T}}=0.53\right)$, UK $\left(\mathrm{X}_{\mathrm{UK}}=0.48\right)$, Malta $\left(\mathrm{X}_{\mathrm{M}}=0.30\right)$.

\section{The Usage of Mobile Technological Devices}

Results of the ANOVA test for comparing the use of mobile technologies in each country are presented in Table 3. 
Table 3

ANOVA Test based on Usage of Mobile Technological Devices

\begin{tabular}{|c|c|c|c|c|c|c|c|}
\hline & Source of variation & $\begin{array}{l}\text { Sum of } \\
\text { squares }\end{array}$ & df & $\begin{array}{l}\text { Means of } \\
\text { squares }\end{array}$ & $\mathbf{F}$ & $\mathbf{p}$ & $\begin{array}{l}\text { Significant } \\
\text { Variation }\end{array}$ \\
\hline Notebook & $\begin{array}{l}\text { Among groups } \\
\text { Within groups } \\
\text { Total }\end{array}$ & $\begin{array}{l}0.232 \\
10.494 \\
10.727\end{array}$ & $\begin{array}{l}2 \\
440 \\
442\end{array}$ & $\begin{array}{l}0.116 \\
.024\end{array}$ & 4.871 & $0.008^{* *}$ & $2-1$ \\
\hline Tablet & $\begin{array}{l}\text { Among groups } \\
\text { Within groups } \\
\text { Total }\end{array}$ & $\begin{array}{l}2.793 \\
84.701 \\
87.494\end{array}$ & $\begin{array}{l}2 \\
440 \\
442\end{array}$ & $\begin{array}{l}1.397 \\
.193\end{array}$ & 7.255 & $.001 * *$ & $2-1,3-1$ \\
\hline Smartphone & $\begin{array}{l}\text { Among groups } \\
\text { Within groups } \\
\text { Total }\end{array}$ & $\begin{array}{l}5.204 \\
47.396 \\
52.600\end{array}$ & $\begin{array}{l}2 \\
440 \\
442\end{array}$ & $\begin{array}{l}2.602 \\
108\end{array}$ & 24.157 & $.000^{* *}$ & $1-2,1-3$ \\
\hline
\end{tabular}

*p<.05, **p<.01, 1-Turkey, 2-Malta, 3-UK

In Table 3, a significant difference is shown among countries in the use of Notebook $(\mathrm{F}=4.87, \mathrm{p}$ $<.01)$; Tablet $\mathrm{PC}(\mathrm{F}=7.26, \mathrm{p}<.01)$; and Smartphone $(\mathrm{F}=24.16, \mathrm{p}<.01)$. Post hoc significant difference (Scheffe) results were interpreted in order to find which countries had difference on the use of mobile technologies. As it can be seen from these results, the difference in the use of Notebook is between Turkey and Malta; for the use of Tablet PC and Smartphone between Turkey and Malta, and the UK as well.

The use of Notebooks is very popular amongst participants with Malta leading $(\mathrm{X}=1.0)$, closely followed by the UK $\left(X_{U K}=99.2\right)$ and Turkey $\left(X_{T}=0.95\right)$.

While participants from Turkey lead in positive responses regarding the use of Smartphones $\left(\mathrm{X}_{\mathrm{T}}\right.$ $=0.98)$ followed by the UK $\left(X_{U K}=0.78\right)$ and Malta $\left(X_{M}=0.74\right)$, the UK participants take the lead in the use of Tablets $(\mathrm{X}=0.35)$ followed by Malta $\left(\mathrm{X}_{\mathrm{M}}=0.33\right)$, and Turkey $\left(\mathrm{X}_{\mathrm{T}}=0.18\right)$.

\section{The Usage of Online Information Sources}

Results of the ANOVA test for comparing variation of participants in different countries based on the information sources are presented in Table 4.

Table 4

ANOVA Test based on the Usage of Online Information Sources Variable

\begin{tabular}{|c|c|c|c|c|c|c|c|}
\hline & $\begin{array}{l}\text { Source of } \\
\text { variation }\end{array}$ & $\begin{array}{l}\text { Sum of } \\
\text { squares }\end{array}$ & df & $\begin{array}{l}\text { Means of } \\
\text { squares }\end{array}$ & $\mathbf{F}$ & $\mathbf{p}$ & $\begin{array}{l}\text { Significant } \\
\text { Variation }\end{array}$ \\
\hline $\begin{array}{l}\text { search } \\
\text { engine }\end{array}$ & $\begin{array}{l}\text { Among groups } \\
\text { Within groups } \\
\text { Total }\end{array}$ & $\begin{array}{l}3.951 \\
163.065 \\
167.016\end{array}$ & $\begin{array}{l}2 \\
440 \\
442\end{array}$ & $\begin{array}{l}1.975 \\
.371\end{array}$ & 5.330 & .005 & $1 \sim 2$ \\
\hline wiki & $\begin{array}{l}\text { Among groups } \\
\text { Within groups } \\
\text { Total }\end{array}$ & $\begin{array}{l}67.307 \\
467.686 \\
534.993\end{array}$ & $\begin{array}{l}2 \\
440 \\
442\end{array}$ & $\begin{array}{l}33.654 \\
1.063\end{array}$ & 31.661 & .000 & $1 \sim 2.1 \sim 3.3 \sim 2$ \\
\hline $\begin{array}{l}\text { social } \\
\text { networks }\end{array}$ & $\begin{array}{l}\text { Among groups } \\
\text { Within groups } \\
\text { Total }\end{array}$ & $\begin{array}{l}88.246 \\
671.984 \\
760.230\end{array}$ & $\begin{array}{l}2 \\
440 \\
442\end{array}$ & $\begin{array}{l}44.123 \\
1.527\end{array}$ & 28.891 & .000 & $1 \sim 2.1 \sim 3$ \\
\hline blog & $\begin{array}{l}\text { Among groups } \\
\text { Within groups } \\
\text { Total }\end{array}$ & $\begin{array}{l}49.541 \\
519.353 \\
568.894\end{array}$ & $\begin{array}{l}2 \\
440 \\
442\end{array}$ & $\begin{array}{l}24.770 \\
1.180\end{array}$ & 20.986 & .000 & $1 \sim 2.1 \sim 3$ \\
\hline $\begin{array}{l}\text { digital } \\
\text { libraries }\end{array}$ & $\begin{array}{l}\text { Among groups } \\
\text { Within groups } \\
\text { Total }\end{array}$ & $\begin{array}{l}28.625 \\
509.439 \\
538.063\end{array}$ & $\begin{array}{l}2 \\
440 \\
442\end{array}$ & $\begin{array}{l}14.312 \\
1.158\end{array}$ & 12.361 & .000 & $2 \sim 1.3 \sim 1$ \\
\hline $\begin{array}{l}\text { digital } \\
\text { newspap } \\
\text { ers }\end{array}$ & $\begin{array}{l}\text { Among groups } \\
\text { Within groups } \\
\text { Total }\end{array}$ & $\begin{array}{l}.119 \\
613.981 \\
614.099\end{array}$ & $\begin{array}{l}2 \\
440 \\
442\end{array}$ & $\begin{array}{l}.059 \\
1.395\end{array}$ & .043 & .958 & no significant \\
\hline
\end{tabular}

*p<.05, **p<.01, 1-Turkey, 2-Malta, 3-UK 
Table 4 shows a significant difference in the results of the ANOVA test among countries for the use of search engines $(\mathrm{F}=5.33, \mathrm{p}<.01)$; wiki $(\mathrm{F}=31.66, \mathrm{p}<.01)$; social networks $(\mathrm{F}=28.89, \mathrm{p}<.01)$; blogs $(\mathrm{F}=20.99, \mathrm{p}<.01) ;$ digital libraries $(\mathrm{F}=12.36, \mathrm{p}<.01) ;$ Libraries $(\mathrm{F}=4.29, \mathrm{p}<.05) ;$ printed newspapers $(\mathrm{F}=10.61, \mathrm{p}<.01)$; printed scientific journals $(\mathrm{F}=4.80, \mathrm{p}<.01)$; printed books $(\mathrm{F}=5.18$, $\mathrm{p}<.01)$; and printed lecture notes $(\mathrm{F}=21.67, \mathrm{p}<.01)$. Post hoc significant difference (Scheffe) results were interpreted in order to find which countries had differences on the use of information sources. According to this, the difference in the use of search engines and printed books is between Turkey (X $=4.78$ and $\mathrm{X}=3.43)$ and Malta $(\mathrm{X}=4.56$ and $\mathrm{X}=3.03)$. In the use of social networks $\left(\mathrm{X}_{\mathrm{T}}=3.53, \mathrm{X}_{\mathrm{M}}=\right.$ 2.48, and $\left.\mathrm{X}_{\mathrm{UK}}=2.86\right)$, blogs $\left(\mathrm{X}_{\mathrm{T}}=3.16, \mathrm{X}_{\mathrm{M}}=2.50\right.$, and $\left.\mathrm{X}_{\mathrm{UK}}=2.48\right)$, digital libraries $\left(\mathrm{X}_{\mathrm{T}}=3.15, \mathrm{X}_{\mathrm{M}}=\right.$ 3.74 , and $\left.\mathrm{X}_{\mathrm{UK}}=3.55\right)$, and printed lecture notes $\left(\mathrm{X}_{\mathrm{T}}=4.05, \mathrm{X}_{\mathrm{M}}=3.25\right.$, and $\left.\mathrm{X}_{\mathrm{UK}}=3.54\right)$ is between Turkey and Malta, and Turkey and the UK respectively as well. The differences in the use of Libraries and printed scientific journals is between Turkey $(X=2.85$ and $X=2.69)$ and the UK $(X=3.22$ and $X$ $=2.31$ ), respectively. Finally, in the use of wiki a significant difference exists between Turkey and Malta $\left(X_{T}=3.77, X_{M}=2.83\right)$, Turkey and the UK $\left(X_{T}=3.77, X_{U K}=3.29\right)$, and Malta and the UK $\left(X_{M}=2.83\right.$, $\mathrm{X}_{\mathrm{UK}}=3.29$ ).

\section{Discussion, Conclusion and Recommendations}

The findings of this study, which is based on the usage levels of social networks, mobile technologies, and online information sources frequently used in accessing information, have shown significant differences in terms of the types of social networks used in the UK, Malta, and Turkey. According to this, Facebook is used more in Malta and Turkey than the UK. Twitter, Instagram and Snapchat are used more in Turkey and the UK in comparison to Malta. When these findings are considered together with the work carried out by Özerbaş and Kuralbayeva (2018), the findings can be explained in terms of the differences in digital literacy between countries. In addition to this, the findings of the work carried out by Aydın (2016) are important in explaining the findings of this work. The findings show that in Turkey, university students use social networks to communicate with their friends, and the one mainly used is Facebook. At this point, the information accessed becomes more important. In their work, Odabaş, Odabaş and Sevmez (2018) questioned the trends amongst university students about the sort of reading environments and materials. The responses were that students preferred to access information through social networks and did not prefer reading digital books/e-books. According to the digital report collaboratively prepared by We are Social and Hootsuite (2018), the use of Instagram is in rise in Turkey; so much that they call it the lovemark of the Turks. Sar1 and Kunt (2014) stated that as the seniority of students increases, the use of the Internet is increasingly used for socialising and chats in addition to accessing information. Taking this into account, it is expected that the use of social networks to access information in Turkey will be more than the other two countries. However, while the use of social networks reaches 67 percent in the UK, the same is only 63 percent in Turkey (We are Social and Hootsuite, 2019). It is important to look into the reasons behind less use of the social media in the UK in accessing information compared to Turkey, while the former has a higher rate of access to information. It will be fair to say that, in the UK, the students are more conscious of the untrustworthiness of social media in accessing correct information; this is an indication of the level of literacy and awareness.

When the differences in the use of mobile technologies in accessing information in the UK, Malta, and Turkey are compared, while the use of notebooks leads in Malta, the main communication technology used in Turkey is smartphones. In the use of tablets to access information, Malta and the UK are ahead of Turkey. Research shows that amongst the countries leading in reading books, France and the UK lead with 21 percent (UNESCO, 2017). The advantage of reading books tablets offer because of their larger screens may be the reason behind the preference of digital publications (articles, novels etc.). The same research showed that percentage of the population reading books is at 0.1 . Each of these three countries, follow educational policies in favour of providing tablets and notebooks to students and teachers as part of technology integration into education. This indicates that Turkey is lagging in technology integration aiming at the use of technology to access information. In a study carried out by Pamuk, Çakır, Ergun, Yılmaz and Ayas (2013) on the Fatih project, one-to-one and group interviews with students showed that the use of tablets is a lot less than the use of smart boards. The main reason behind this has been identified as technical limitations of tablets and lack of 
resources/contents. The same study showed that in addition to students, teachers rarely use tablets too. This can be explained by socio-economic and cultural structures of the society as well as habits the population has. According to the findings of the Global Mobile Users questionnaire carried out by Deloitte (2018a), in Turkey, the use of mobile services is in rise, so that 92 percent of the participants own a smartphones followed by 81 percent of laptop and 63 percent of tablet ownership. It is also stated that, in $2014,1.57$ billion people owned a smartphones. This number is projected to reach to 2.87 billion by 2020 (BTK, 2018, from TRT Haber, 2019). In addition to this, the percentage use of smartphones in The UK is 77 followed by 64 percent usage of tablets (Deloitte, 2018b). Following from this, it is believed that the limited use of smartphones in accessing information in The UK is caused by the subjects on media literacy taught as part of the curriculum, and the effective implementation of technology integration in education. It can only be added that, due to the teaching stated above, the students are conscious of the negative aspects of the use of smartphones and behave accordingly (Tanriverdi and Apak, 2010). The influence of British culture on Maltese education and culture, in general, explains the findings of the work done.

When the findings on the online resources used to access information in the UK, Malta, and Turkey are compared, Turkey leads in the use of Search Engines, Wikis, Social Networks, and Blogs. Only in the use of Digital Libraries, Turkey lags behind both Malta and the UK. This may well be linked to the low rate of book reading in Turkey (UNESCO, 2017). After all, a population that does not read is not expected to use digital libraries much. This situation can be used as an opportunity by educationalists in Turkey. Social networks can be used for educational purposes together with digital stories and blogs to deliver information to students and develop reading habits. In the UK, the use of Wikipedia by university students was studied. It is found that the use of Wikipedia in the UK is not for academic purposes (Knight and Pryke, 2012). This is because educational establishments discourage the use of Wikipedia considering it unreliable. Although access to Wikipedia is not allowed in Turkey, it is well known that students use Wikipedia rather than digital libraries in completing their homework as well as final projects. This is because the digital databases students can access in Turkey demand payment, students are not aware of the digital databases universities subscribe to, and students do not know how to use digital databases for research.

The findings of this work show that Turkey is ahead of the UK and Malta in the use of digital environments. When the level of development is considered, this does not look right. Although Turkey leads in the use of digital resources, this does not reflect in production and development. This is supported by the fact that while ICT and programming courses offered in the curriculum aimed at developing literacy in these fields in Turkey, the same courses are used to enable students to develop systems by the use of computing technologies (Barut and Kuzu, 2017). In Turkey, however, in teaching science and technology at primary schools, the use of ICT is supported which partially reflects in benefits, and level of education students have. Göldağ and Kanat (2018) state in their work that the increased use of the Internet by students does not reflect in digital literacy. The interpretation of these findings is that students do not use internet sites consciously; they rather use the Internet for entertainment and chats. A comparative study carried out by Tanriverdi and Apak (2010) showed that in countries having a well-developed education system such as Finland and Ireland, media literacy course is offered as a unit in the curriculum to develop skills, behaviour, values and understanding, and rather than protecting individuals it aims at developing awareness. On the other hand in Turkey, media literacy is focused on accessing information and understanding subject with application and skill development at times. This is an area where the effects of differences in knowledge and behaviour on the changes in digital literacy can be researched. In Turkey, it is possible to have functional politics on focus on the activities on the use of correct sources to access correct information. In introducing digital literacy into the curriculum, the first step should be having correct policies. At this point, the graduates of Computer and Teaching Technologies Education can play an important role. The importance of socio-economic and cultural aspects should also be taken into consideration in any work to follow. It is anticipated that a society that reads one minute a day on average has fundamental problems. Because the majority of university students do not read unless they have to (Odabaş, Odabaş, and Sevmez, 2018), it looks almost impossible to enable the favourable use of latest technologies and digital literacy, unless the educational system and students views on literacy are changed, and their awareness of such technologies is increased. To overcome this problem, it is important to offer digital literacy education 
at all levels of educational life and include parents in there too. This will provide a common platform for all members of society. This may enable young children to overcome the risks such as content, behaviour, and contact in digital environments; university students develop their strategies to access correct information learning how to use these strategies in using their universities digital libraries and databases and shaping their learning attitudes accordingly to help their scientific research skills; parents will develop an awareness of applications and behaviours that are important in their children's psychosocial and cultural development helping them in their development and digital literacy. In addition, it is important to investigate why students from different cultures use different applications and equipment in accessing information. It is also possible to integrate digital literacy education into national curriculum and every field of university education as well as lifelong learning programs.

\section{References}

Aydın, İ. E. (2016). Üniversite öğrencilerinin sosyal medya kullanımları üzerine bir araştırma: Anadolu Üniversitesi örneği [A study on usage of social media among univerty students:Anadolu University Case]. Selçuk Üniversitesi Sosyal Bilimler Enstitüsü Dergisi [Journal of Selcuk University Institute of Social Sciences], (35), 373-386.

Artemova, A. (2018). Engaging generation Z through social media marketing. Licence Thesis, SouthEastern Finland University of Applied Sciences.

Barut, E. \& Kuzu A. (2017). Türkiye ve İngiltere bilişim teknolojileri öğretim programlarının amaç, kazanım, etkinlik, ölçme ve değerlendirme süreçleri açısından karşılaştırılması [The comparison of turkey and uk's information technologies curriculum in the context of objectives, acquisition, activities, measurement and evaluation]. Trakya Üniversitesi Ĕ̈itim Fakültesi Dergisi [Trakya University Journal of Education], 7(2), 721-745. DOI: 10.24315/trkefd.303156

Bilgiç, H. G., Duman, D. \& Seferoğlu, S. S. (2011). Dijital yerlilerin özellikleri ve çevrim içi ortamların tasarlanmasindaki etkileri [The characteristics of digital natives' and their effects of on the design of online environments]. Akademik Bilişim, 2011, 2-4 Şubat, İnönü Üniversitesi-Malatya [Academic Informatics 2011, 2-4 February, Inonu University-Malatya, 1-7].

Deloitte, (2018a). Global Mobile User Survey [Küresel Mobil Kullanıcı Anketi]. Retrieved from online https://www2.deloitte.com/tr/tr/pages/technology-media-and-telecommunications/articles/globalmobile-consumer-survey-us-edition.html on 20.07.2019.

Deloitte, (2018b). Global Mobile Consumer Survey 2018: The UK Cut [Küresel Mobil Tüketici Anketi 2018: Birleşik Krallık]. Retirieved online from http://www.deloitte.co.uk/mobileuk/\#uksmartphone-and-tablet-penetration-among-55-75-year-olds on 20.07.2019.

Etikan, I., Musa, S. A. \& Alkassim, R. S. (2016). Comparison of convenience sampling and purposive sampling. American journal of theoretical and applied statistics, 5(1), 1-4.

Fraenkel, J. R. \& Wallen, N. E. (2006). How to design and evaluate research in education.

Gezgin, D. M., Hamutoğlu, N. B., Samur, Y. \& Yildirim, S. (2018). Genç nesil arasında yaygınlaşan bir bağımlılık: Akıllı telefon bağımlılı̆̆ının cinsiyet, akademik başarı ve mobil oyun oynama değişkenleri açısından incelenmesi [A spreading addiction among young generation: An examination of smartphone addiction according to gender, academic success and mobile game playing variables]. Eğitim Teknolojiji Kuram ve Uygulama [Educational Technology Theory and Practice], 8(2), 212-231.

Göldağ, B. \& Kanat S. (2018). Güzel sanatlar eğitimi alan öğrencilerin dijital okuryazarlık durumları [Digital literacy status of the students who studied fine arts education]. The Journal of Academic Social Science Studies, 70, 77-92. DOI: 10.9761/JASSS7736

Gülbahar, Y., Kalelioğlu, F. \& Madran, R. O. (2010). Sosyal ağların eğitim amaçlı kullanımı [Educational use of social networks]. XV. Türkiye'de İnternet Konferans1, İstanbul Teknik Üniversitesi, 2-4 Aralı, İstanbul [XV. Internet Conference in Turkey, Istanbul Technical University, 2-4 December, Istanbul]. 
ICT Facts and Figures (2019). ITU. Retrieved from http://www.itu.int/en/ITUD/Statistics/Documents/facts/ICTFactsFigures2016.pdf on 10 June 2020.

Karaman, S., Yıldırım, S. \& Kaban, A., (2008). Öğrenme 2.0 yaygınlaşıyor: Web 2.0 uygulamalarının eğitimde kullanımına iliş̧kin araştırmalar ve sonuçları [Learning 2.0 is spreading: Research and results on the use of Web 2.0 applications in education]. İnettr'08- XIII. Türkiye'de İnternet Konferansı Bildirileri. 22-23 Aralık ,Orta Doğu Teknik Üniversitesi, Ankara [İnettr'08- XIII. Internet Conference Proceedings in Turkey. 22-23 December, Middle East Technical University, Ankara].

Knight, C. \& Pryke, S. (2012). Wikipedia and the University, a case study. Teaching in Higher Education, 17(6), 649-659.

Leitch, S. \& Warren, M. J. (2011). Social networking and teaching: An Australian Case Study. Proceedings of Informing Science \& IT Education Conference (InSITE) 2011. Deakin University, Burwood, Victoria, Australia.

Lucky, A. (2017). The list of millennial characteristics. Retrieved from http://luckyattitude.co.uk/millennial- characteristics/ on 06.12.2019.

Norman, H., Nordin, N., Din, R., Ally, M. \& Dogan, H. (2015). Exploring the roles of social participation in mobile social media learning: A social network analysis. International Review of Research in Open and Distributed Learning, 16(4), 205-224.

Odabaş, H., Odabaş, Z. Y. \& Sevmez, H. (2018). Üniversite öğrencilerinde dijital/e-kitap okuma kültürü: Selçuk Üniversitesi örneği [Digital / E-Book reading culture in university students: Selçuk university sample]. Ankara Üniversitesi Dil ve Tarih-Coğrafya Fakültesi Dergisi [The Journal of the Faculty of Languages and History-Geography], 58(1), 139-171. DOI: 10.33171/dtcfjournal.2018.58.1.8

Özerbaş, M. A. \& Kuralbayeva, A. (2018). Türkiye ve Kazakistan öğretmen adaylarının dijital okuryazarlık düzeylerinin değerlendirilmesi [A review of digital literacy levels of future primaryschool and secondary-school teachers in Turkey and Kazakhstan]. Muğla Sitkı Koçman Üniversitesi Ĕ̈itim Fakültesi Dergisi [Muğla Sitkı Koçman University Journal of Education], 5(1), 16-25. DOI: 10.21666/muefd.314761.

Pamuk, S., Çakır, R., Ergun, M., Yılmaz, H. B. \& Ayas, C. (2013). Öğretmen ve öğrenci bakış açısıyla tablet PC ve etkileşimli tahta kullanımı: FATíH Projesi değerlendirmesi [The use of tablet pc and interactive board from the perspectives of teachers and students: Evaluation of the FATIH Project]. Kuram ve Uygulamada Ĕ̈itim Bilimleri [Educational Sciences: Theory \& Practice], 13(3), 17991822., 13(3). DOI: 10.12738/estp.2013.3.1734.

PISA (2018). PISA 2018 Türkiye Ön Raporu [PISA 2018 Turkey Preliminary Report]. Retrieved from http://pisa.meb.gov.tr/wp-content/uploads/2020/01/PISA_2018_Turkiye_On_Raporu.pdf, on 19.05.2020.

Prensky, M. (2001). Digital natives, digital immigrants. Retrieved from http ://www. marcprensky. com/writing/Prensky \%20-\%20Digital\%20Natives,\%20Digital\%20 Immi grants\%20-\%20Part1 .pdf] on 18.05.2020.

Sahin, A., Kaynakçi, C. \& Aytop, Y. (2016). Ziraat fakültesi öğrencilerinin sosyal medya kullanım alışkanlıklarının belirlenmesi [Determination of social media usage habits of students in the agriculture faculty]. Tekirdağ Ziraat Fakültesi Dergisi [Journal of Tekirdag Agricultural Faculty], 13(2), 34 .

Saleh, Z. I. \& Mashhur, A. S., (2015). The Impact of e-Books on the Printed Books: e-Books Popularity, Growth and Future.

Sanders, J. \& Morrison, C. (2007). What is the Net Generation? The challenge for future medical education, Med., Teach., 29(2-3), 85-88. 
Sarı, S. \& Kunt, H. (2014). İlkokul ve ortaokul öğrencilerinin sınıf düzeylerine göre internet kullanım durumlarının incelenmesi [Determining the internet usage of primary and secondary school students according to their grade]. Dumlupinar Üniversitesi Sosyal Bilimler Dergisi [Dumlupinar University Journal of Social Sciences, 40.

Tanrıverdi, B. \& Apak, Ö. (2010). Türkiye, Finlandiya ve İrlanda ilköğretim programlarının medya okur-yazarlığı eğitimi açısından karşılaştırılması [Analysis of primary school curriculum of turkey, finland, and ireland in terms of media literacy education]. Kuram ve Uygulamada Eğitim Bilimleri [Educational Sciences:Theory and Practice], 10(2), 1153-1213.

Taş, H. Y., Demirdöğmez, M. \& Küçükoğlu, M. (2017). Geleceğimiz olan Z kuşağının çalışma hayatına muhtemel etkileri [Possible effects of future architects' z generation on business life]. OPUSUluslararası Toplum Araştırmaları Dergisi [International Journal of Society Researchs], 7(7), 1033-1048. DOI: 10.26466/opus.370345.

Togay, A., Akdur, T. E., Yetişken, İ. C. \& Bilici, A. (2013). Eğitim süreçlerinde sosyal ağların kullanımi: Bir MYO deneyimi [The usage of social networks in education processes: A vocational high school experience]. Akademik Bilişim Konferans1, Antalya: Akdeniz Üniversitesi [Academic Informatics Conference, Antalya: Akdeniz University].

Tonta, Y. (2009). Digital natives, social networks and the future of libraries. [Dijital yerliler, sosyal ağlar ve kütüphanelerin geleceği]. Türk Kütüphaneciliği [Turkish Librarianship],23(4),742-768.

TRT Haber (2019). Dünyada cep telefonu kullanıcı sayısı 4,5 milyarı aştı [The number of mobile phone users worldwide has exceeded 4.5 billion]. Retrieved from https://www.trthaber.com/haber/dunya/dunya-genelinde-cep-telefonu-kullananlarin-sayisi-45milyari-gecti-402379.html on 16.07.2019.

UNDP (2019). 2019 İnsani Geliş̧me Raporu: 21. Yüzyılda İnsani Gelişmedeki Eşitsizlikler [Human Development Report 2019: Inequalities in Human Development in the 21st Century]. Retrieved from https://www.tr.undp.org/content/turkey/tr/home/library/human_development/hdr2019.html on 19.05.2020.

UNESCO (2017). UNESCO: Türkiye kitap okuma oranında 86. Sırada [UNESCO: Turkey ranks 86th in book reading rate]. Retrieved from https://www.cnnturk.com/dunya/dw/unesco-turkiye-kitapokuma-oraninda-86inci-sirada, on 14.07.2019.

We Are Social \& Hooutsuite (2019). Global Internet Usage Speeds [Küresel İnternet Kullanım Hızları]. Retrieved from https://wearesocial.com/global-digital-report-2019 and https://digitalreport.wearesocial.com/ on 20.07.2019. 